\title{
Ectomycorrhizal colonization of Alnus acuminata Kunth in northwestern Argentina in relation to season and soil parameters
}

\author{
Alejandra BECERRA ${ }^{\mathrm{a} *}$, Karin PRITSCH $^{\mathrm{b}}$, Nilda ARRIGO ${ }^{\mathrm{c}}$, Martha PALMA $^{\mathrm{c}}$, Norberto BARTOLONI ${ }^{\mathrm{d}}$ \\ a Instituto Multidisciplinario de Biología Vegetal (CONICET), C.C. 495, 5000, Córdoba, Argentina \\ ${ }^{b}$ Institute of Soil Ecology, GSF-National Research Centre for Environment and Health GmbH, Neuherberg, Ingolstaedter Landstrasse 1, \\ 85764 Oberschleissheim, Germany \\ c Cátedra de Edafología, Facultad de Agronomía, UBA, Argentina \\ d Cátedra de Métodos Cuantitativos Aplicados, Facultad de Agronomía, UBA, Argentina
}

(Received 14 April 2004; accepted 27 September 2004)

\begin{abstract}
The objective of this study was to determine patterns of ECM colonization of Andean alder at two natural forests in relation to soil parameters at two different seasons (autumn and spring). The soil parameters studied were field capacity, $\mathrm{pH}$, electrical conductivity, available $\mathrm{P}$, total $\mathrm{N}$ and organic matter. Twelve ECM morphotypes were found on A. acuminata roots. The ECM colonization varied among soil types and was affected positively by electrical conductivity. Multiple regression relationships among ECM colonization and edaphic properties variables showed no significant differences at two seasons and among soil types with respect to morphotype diversity values. Positive correlations were found between three morphotypes (Cortinarius tucumanensis, Gyrodon monticola and Russula alnijorrulensis) and soil types and two other morphotypes (Naucoria escharoides and Lactarius sp.) between two seasons. Results of this study provide evidence that ECM colonization of A. acuminata is affected by some chemical edaphic parameters and indicate that some ECM morphotypes are sensitive to changes in seasonality and soil parameters.
\end{abstract}

Alnus acuminata / ectomycorrhizal diversity / Andean forest / soil type

Résumé - Colonisation ectomycorrhizienne d'Alnus acuminata Kunth au nord-ouest de l'Argentine en relation avec la saison et quelques paramètres du sol. Le but de cette étude était de déterminer, au cours de deux différentes saisons (août et printemps), les modèles de colonisation de l'aulne andin dans deux forêts naturelles en relation avec quelques paramètres de sol. Les paramètres de sol étudiés étaient la capacité au champ, le $\mathrm{pH}$, la conductivité électrique, le $\mathrm{P}$ disponible, le $\mathrm{N}$ total et la matière organique. Douze morphotypes de ECM ont été trouvés sur des racines de A. acuminata. La colonisation par les ECM varie en fonction des types de sols et est affectée positivement par la conductivité électrique. Les relations de régression multiple entre la colonisation de ECM et les variables de propriétés du sol n'ont montré aucune différence significative entre les deux saisons et entre les types de sol pour ce qui concerne des valeurs de diversité morphotypique. Des corrélations positives existent entre Cortinarius tucumanensis, Gyrodon monticola et Russula alnijorrulensis et les types de sol, et entre Naucoria escharoides et Lactarius sp. et les deux saisons. Les résultats de cette étude mettent en évidence que la colonisation de ECM de A. acuminata est affectée par quelques paramètres édaphiques chimiques et indiquent que quelques morphotypes de ECM sont sensibles aux changements des paramètres saisonniers et pédologiques.

Alnus acuminata / diversité ectomycorrhizienne / forêt Andine / type de sol

\section{INTRODUCTION}

Alnus acuminata Kunth (Andean alder) a member of the Betulaceae, is distributed along the Andes from Venezuela to latitude $28^{\circ} \mathrm{S}$ in northwestern Argentina [21]. Given its ability to form ectomycorrhizal (ECM), endomycorrhizal and actinorrhizal relationships [14], A. acuminata is tolerant to infertile soils. It grows rapidly and improves soil fertility by increasing soil nitrogen, organic matter, and cation-exchange capacity [21]. Andean alder is mainly harvested for firewood, pulp, and timber. It is an important species recommended for management in land reclamation, watershed protection, agroforestry, and erosion control [35].

From studies on ectomycorrhizae of alder species in North America, Europe and South America, it is known that ectomycorrhizal symbionts are dominant on Alnus sp. roots $[9,10,31$, 45, 46]. A. acuminata is associated with a number of ECM fungi belonging to the genera Russula, Lactarius, Inocybe, Laccaria, Cortinarius, Naucoria, Alpova [32, 47, 50]. Ectomycorrhizas are relatively specialized with a distinctive morphology and

\footnotetext{
* Corresponding author: abecerra@imbiv.unc.edu.ar
} 
physiology [4]. Morphologically distinct ectomycorrhizas resulting from colonization by different fungi on the same host, may exhibit different physiological properties.

The importance of mycorrhizal fungi in the mineral nutrition of the host plant depends on the ability of the fungi to exploit sources of non-mobile nutrients in the soil. Factors such as root properties, soil or climate type, soil organisms, soil disturbance and host-fungus compatibility, may influence the occurrence and effectiveness of mycorrhizal associations [13]. Ectomycorrhizal activities have been reported to occur both in organic matter and in mineral horizons, at least to a depth of $35 \mathrm{~cm} \mathrm{[33].}$

Ectomycorrhizal species composition and diversity react to changing soil conditions [46]. Studies that focus on the relationship between edaphic factors and mycorrhizas are lacking as stated by Swaty et al. [52], Newbery et al. [38], Moyersoen et al. [34] and El Karkouri et al. [16]. This work was carried out to determine the phenology and diversity of the ECM in natural forests of $A$. acuminata in relation to some soil parameters (field capacity, $\mathrm{pH}$, electrical conductivity, available $\mathrm{P}$, total $\mathrm{N}$ and organic matter) at two different seasons (spring and autumn). The soils of this study belong to the Ustorthent order which represents young soils with little depth, and no horizontal differentiation [43]. With these characteristics we expected to find poor levels of nutrients and an ECM colonization affected by these nutrient levels.

\section{MATERIALS AND METHODS}

\subsection{Sampling sites}

The field sites were located in the NW region of Argentina (NOA), namely: (1) Quebrada del Portugués, Tafí del Valle, (Tucumán Province), elevation $2187 \mathrm{~m} ; 26^{\circ} 58^{\prime} \mathrm{S} 65^{\circ} 45^{\prime} \mathrm{W}$, average precipitation between $1200-1500 \mathrm{~mm}$, the soil is classified as Lythic Ustorthent; and (2) Sierra de Narváez, (Catamarca Province), elevation $1820 \mathrm{~m}$ $27^{\circ} 43^{\prime} \mathrm{S} 65^{\circ} 54^{\prime} \mathrm{W}$, average precipitation of $698 \mathrm{~mm}$, the soil is classified as Typic Ustorthent. Mean annual temperatures range from 5.8 to $24{ }^{\circ} \mathrm{C}$ for both locations. The vegetation is a nearly homogeneous A. acuminata forest (height 6-15 m, age 20-30 years) with few herbaceous understory plants such as Duschesnea sp., Conyza sp., Axonopus sp., Selaginella sp. and Prunella sp. [2].

\subsection{Field collection and laboratory analysis}

Twenty square plots $(10 \times 10 \mathrm{~m})$ were established randomly at each site during spring 1999 and fall 2000. A mature tree (i.e. an individual producing female and male cones) with a trunk diameter of $10-25 \mathrm{~cm}$ was sampled inside each plot and one soil core of $15 \times 15 \mathrm{~cm}^{2}$ and $25 \mathrm{~cm}$ depth excavated at 15 to $50 \mathrm{~cm}$ distance from the tree. The majority of Andean alder roots occurred in the top $20 \mathrm{~cm}$ of the soil at both sites. The samples were placed in plastic bags and stored at $4{ }^{\circ} \mathrm{C}$ during transport to the laboratory.

\subsection{Analysis of root samples}

Every root sample was checked for ECM types and alder roots which were easy to identify due to their morphological appearance were separated. After mycorrhizae were cut off, they were sorted according to their morphological features (color, mantle layers, rizomorphs, lactifers, etc.) under a Zeiss stereo microscope at $\times 10-40$ magnification. For DNA-based identification, several tips of every morphotype as well as small fruitbody pieces of potential mycorrhizal fungi were prepared for DNA extraction. For PCR, primers ITS1/ITS4 [58] were used and PCR conditions were as described by Henrion et al. [25]. PCR-products were subsequently cleaved with the restriction endonucleases TaqI, HinfI and EcoRI. Restriction patterns were compared visually, and for identical patterns fragment lengths were determined $[9,10]$. For those morphotypes where no matches were found within the ITS-PCR/RFLP patterns, ITS-PCR products were sequenced in duplicate using ITS1 and ITS4 as the sequencing primers. The resulting sequences were aligned and the respective resulting consensus sequence was compared to the NCBI database using BlastN [Becerra et al., unpublished]. Unidentified mycorrhizas were termed according to Agerer [3] using the genus of the tree species completed by "rhiza" and a describing epithet. Twelve ECM types could be characterized in this way and they have been described in detail [8]. A brief description of their most prominent morphological and anatomical features is given in Table I.

\subsection{Quantification}

The percentage of root tips colonized by ECM was determined as described by Gehring and Whitham [19]. ECM roots were distinguished from non ECM roots by the occurrence of a fungal mantle. The roots in each sample were divided for operative reasons into three subsamples due to the large number of root tips per sample (200400 tips). The roots of each subsample were randomly distributed on a tray of 54 equal compartments each measuring $2.5 \times 2.5 \mathrm{~cm}$ and all the roots within the compartments were counted. Percentage ECM colonization was calculated as the number of ECM root tips divided by the total number of root tips [19]. Percent colonization for each ECM morphotype was calculated for each sampled tree by dividing the number of root tips of each ECM type by the total number of root tips, and multiplying by 100 [24].

Diversity of mycorrhizal morphotypes was calculated by Simpson's dominance index (SR) [49] using the mean relative percentage of each morphotype associated with each tree. Relative colonization of morphotype $t$ on a root system was calculated by dividing the percentage of morphotype $t$ by the total percentage:

$$
S R=\left(\sum_{t=1}^{m} p_{t}^{2}\right)^{-1}
$$

where $p_{t}$ is the relative colonization of ECM morphotype $t$ and $m$ is the number of ECM morphotypes. Simpson's diversity index tends to be less sensitive to sample size and minor species compared with other diversity indexes [23].

\subsection{Soil analysis}

Soil samples were air-dried and sieved $(2 \mathrm{~mm})$ and the $\leq 2 \mathrm{~mm}$ fraction was analyzed as follows. Field capacity was determined in a previously saturated sample of soil ( $1 \mathrm{~cm}$ thick), after being subjected to a centrifugal force of 1000 times gravity for $30 \mathrm{~min}$ [55]. Soil $\mathrm{pH}$ was determined with a glass electrode in soil water relation 1:2.5 (w/w) [40]. Electrical conductivity of a saturation extract was measured at $25^{\circ} \mathrm{C}$ following Bower and Wilcox [11]. Available phosphorus was determined using the method Bray and Kurtz I [26] by relating the spectral absorbance of the sample and that of a standard. Total nitrogen was determined using the micro-Kjeldhal method [12]. Organic matter content was determined following the method by Nelson and Sommers [36].

\subsection{Statistical analysis}

The influence of two treatments (sampling dates and study site) and six independent covariates (field capacity, $\mathrm{pH}$, electrical conductivity, 
Table I. Brief description of morphological and anatomical characters of 12 morphotypes of Alnus acuminata.

\begin{tabular}{|c|c|c|c|c|c|}
\hline Name & $\begin{array}{l}\text { Mantle colour, type and } \\
\text { thickness }^{\mathrm{a}}\end{array}$ & Root morphology & $\begin{array}{l}\text { Emanating elements } \\
\text { (hyphae diameter) }\end{array}$ & $\begin{array}{l}\text { Hartig } \\
\text { net }^{\mathrm{b}}\end{array}$ & Differentiating features \\
\hline $\begin{array}{l}\text { Cortinarius } \\
\text { helodes }\end{array}$ & $\begin{array}{l}\text { White to beige mantle, } \\
\text { plect. }(219 \mu \mathrm{m})\end{array}$ & $\begin{array}{l}\text { Simple ramification, } \\
\text { straight to tortuous tips }\end{array}$ & $\begin{array}{l}\text { Numerous hyaline hyphae with smooth } \\
\text { surface }(2-11 \mu \mathrm{m})\end{array}$ & Paraep. & Thick mantle \\
\hline $\begin{array}{l}\text { Cortinarius } \\
\text { tucumanensis }\end{array}$ & $\begin{array}{l}\text { Silvery, whitish mantle, } \\
\text { plect. }(101 \mu \mathrm{m})\end{array}$ & $\begin{array}{l}\text { Simple ramification, } \\
\text { tortuous tips }\end{array}$ & $\begin{array}{l}\text { Numerous hyaline hyphae with smooth } \\
\text { surface }(3-8 \mu \mathrm{m})\end{array}$ & Periep. & $\begin{array}{l}\text { Tips with / without } \\
\text { mantle }\end{array}$ \\
\hline $\begin{array}{l}\text { Alnirhiza } \\
\text { metalicans }\end{array}$ & $\begin{array}{l}\text { Silvery, whitish mantle, } \\
\text { plect. }(72 \mu \mathrm{m})\end{array}$ & $\begin{array}{l}\text { Simple ramification, } \\
\text { straight to tortuous tips }\end{array}$ & $\begin{array}{l}\text { Numerous hyaline hyphae with smooth } \\
\text { surface }(2-7 \mu \mathrm{m})\end{array}$ & Paraep. & Many soil particles \\
\hline $\begin{array}{l}\text { Lactarius } \\
\text { omphaliformis }\end{array}$ & $\begin{array}{l}\text { Yellow to red brown } \\
\text { mantle, pseud. }(40 \mu \mathrm{m})\end{array}$ & $\begin{array}{l}\text { Simple to irregular } \\
\text { pinnate, straight tips }\end{array}$ & $\begin{array}{l}\text { Sparse hyaline hyphae with smooth } \\
\text { surface }(2 \mu \mathrm{m})\end{array}$ & Periep. & Laticifers in the mantle \\
\hline $\begin{array}{l}\text { Gyrodon } \\
\text { monticola }\end{array}$ & $\begin{array}{l}\text { Yellow to light brown } \\
\text { mantle, plect. }(57 \mu \mathrm{m})\end{array}$ & $\begin{array}{l}\text { Monopodial to irregular } \\
\text { pinnate, tortuous tips }\end{array}$ & $\begin{array}{l}\text { Numerous hyaline hyphae }(4 \mu \mathrm{m}) \text {, } \\
\text { brown }(5 \mu \mathrm{m}) \text { with smooth surface }\end{array}$ & Paraep. & $\begin{array}{l}\text { Brown cystidia on the } \\
\text { mantle }\end{array}$ \\
\hline Tomentella sp. 1 & $\begin{array}{c}\text { Brown mantle, plect. } \\
\qquad(51 \mu \mathrm{m})\end{array}$ & $\begin{array}{l}\text { Simple to irregular } \\
\text { pinnate, straight tips }\end{array}$ & $\begin{array}{l}\text { Numerous brown hyphae with smooth } \\
\text { surface }(2-6 \mu \mathrm{m})\end{array}$ & Periep. & Acute tips \\
\hline $\begin{array}{l}\text { Naucoria } \\
\text { escharoides }\end{array}$ & $\begin{array}{l}\text { Yellowish to brown } \\
\text { mantle, plect. }(57 \mu \mathrm{m})\end{array}$ & $\begin{array}{l}\text { Simple to monopodial, } \\
\text { straight tips }\end{array}$ & $\begin{array}{l}\text { Numerous hyaline hyphae with smooth } \\
\text { surface }(2-5 \mu \mathrm{m})\end{array}$ & Periep. & $\begin{array}{l}\text { Usually tips without } \\
\text { mantle }\end{array}$ \\
\hline Tomentella sp. 2 & $\begin{array}{l}\text { Dark brown to black } \\
\text { mantle, pseud. }(70 \mu \mathrm{m})\end{array}$ & $\begin{array}{l}\text { Simple to irregular } \\
\text { pinnate, flexuous tips }\end{array}$ & $\begin{array}{l}\text { Sparse brown hyphae with smooth } \\
\text { surface }(2-5 \mu \mathrm{m})\end{array}$ & Periep. & Abundant cystidia ${ }^{c}$ \\
\hline $\begin{array}{l}\text { Russula alnijo- } \\
\text { rullensis }\end{array}$ & $\begin{array}{l}\text { Nacar to light brown } \\
\text { mantle, pseud. }(61 \mu \mathrm{m})\end{array}$ & $\begin{array}{l}\text { Simple to irregular } \\
\text { pinnate, tortuous tips }\end{array}$ & $\begin{array}{l}\text { Sparse hyaline hyphae with smooth } \\
\text { surface }(2-4 \mu \mathrm{m})\end{array}$ & Paraep. & Laticifers in the mantle \\
\hline Tomentella sp. 3 & $\begin{array}{l}\text { Yellowish to grayish } \\
\text { mantle, plect. }(60 \mu \mathrm{m})\end{array}$ & $\begin{array}{l}\text { Monopodial to irregular } \\
\text { pinnate, tortuous tips }\end{array}$ & $\begin{array}{c}\text { Numerous hyaline hyphae smooth } \\
\text { surface }(2-5 \mu \mathrm{m})\end{array}$ & Periep. & Sparse hyphal bundles \\
\hline Lactarius sp. & $\begin{array}{l}\text { Yellow mantle, pseud. } \\
\qquad(35 \mu \mathrm{m})\end{array}$ & $\begin{array}{l}\text { Simple to monopodial } \\
\text { pinnate, tortuous tips }\end{array}$ & $\begin{array}{l}\text { Sparse hyaline hyphae with smooth } \\
\text { surface }(1-3 \mu \mathrm{m})\end{array}$ & Periep. & Latex cells in the mantle \\
\hline $\begin{array}{l}\text { Alnirhiza } \\
\text { amarella }\end{array}$ & $\begin{array}{l}\text { Yellow to beige mantle, } \\
\text { plect. }(52 \mu \mathrm{m})\end{array}$ & $\begin{array}{l}\text { Simple to irregular pin- } \\
\text { nate, flexuous tips }\end{array}$ & $\begin{array}{l}\text { Numerous hyaline hyphae with smooth } \\
\text { surface }(1-3 \mu \mathrm{m})\end{array}$ & Periep. & Acute tips \\
\hline
\end{tabular}

a Plect.: plectenchymatous (hyphae of mantle recognizable as individual hyphae), pseud.: pseudoparenchymatous (hyphae of mantle simulating true parenchyma).

${ }^{b}$ Hartig net: Paraep.: Paraepidermal (penetrating only to the depth of the transverse walls of the epidermal cells), Periep.: Periepidermal (hyphae entirely encircle the epidermal cells) follows Godbout and Fortin [20].

c Urtical like cystidia, Type C [3].

$\mathrm{P}$, total $\mathrm{N}$ and organic matter) upon the ectomycorrhizal colonization was first analyzed through an Analysis of Covariance (ANCOVA).

Multiple regression analysis (linear model) was used to examine the relationships between percentage ECM colonization as response variable [48], soil type and sampling dates. The normality assumption was tested through the Shapiro-Wilk test. No multicolineality was detected among the independent variables. Additionally, inter-site and intra-site regression relationships between soil properties and ECM colonization were analyzed.

Kruskall-Wallis ANOVA test for ranks and $\chi^{2}$ median tests were used to test for differences in the percentage of each morphotype as influenced by soil types and sampling dates, since most data did not follow the assumptions of analysis of variance (ANOVA) even after various transformations.

\section{RESULTS}

Both soils were slightly acidic, but differed in texture and in nutrient content (Tab. II). Due to the higher clay content, soils from Sierra de Narváez (Catamarca province) had higher con- tents of organic matter and $\mathrm{N}$, a higher field capacity and a higher electrical conductivity than soils from Quebrada del Portugués (Tucumán province), which had slightly higher levels in P. The site at Sierra de Narváez presents a lower mean annual precipitation than that at Quebrada del Portugués (698 and $1350 \mathrm{~mm}$ respectively). The values of soil water potential for autumn and spring were $-0.025 \mathrm{MPa}$ and $-0.018 \mathrm{MPa}$ for the Sierra de Narváez site and -0.017 and -0.023 respectively for the Quebrada del Portugués site, while mean spring and autumn temperatures were similar at both locations, with $17^{\circ} \mathrm{C}$ and $10{ }^{\circ} \mathrm{C}$ respectively.

Ectomycorrhizal colonization of $A$. acuminata ranged from 30.3 to $94 \%$. The ECM colonization on roots was not significantly affected by the two sites or the two sampling dates (Tab. III). There was only a slight interaction site $\mathrm{x}$ season effect. These results indicate that ectomycorrhizal colonization was not affected by sites or sampling dates. However, soil parameters (covariates) (field capacity, $\mathrm{pH}$, electrical conductivity, 
Table II. Soil properties of the two sites Quebrada del Portugués (Tucumán) and Sierra de Narváez (Catamarca) as analyzed from soil profiles taken during field work. Mean values of 20 trees. Significance indicated as $*(P<0.05)$.

\begin{tabular}{lcc}
\hline Parameters & Quebrada del Portugués & Sierra de Narváez \\
\hline Soil type & Lythic Ustorthent & Typic Ustorthent \\
Field Capacity (dry weight) & $21.51 \pm 2.12$ & $25.83 \pm 0.12^{*}$ \\
pH 1: 2.5 & $5.20 \pm 0.00$ & $5.15 \pm 0.00$ \\
Electrical conductivity $\left(\mathrm{dS} \mathrm{m}^{-1}\right)$ & $0.11 \pm 0.00$ & $0.61 \pm 0.59^{*}$ \\
Available phosphorus $\left(\mathrm{mg} \mathrm{kg}^{-1}\right)$ & $16.08 \pm 1.19 *$ & $15.83 \pm 2.94$ \\
Total nitrogen $(\%)$ & $0.22 \pm 0.04$ & $0.36 \pm 0.02^{*}$ \\
Organic matter $(\%)$ & $2.58 \pm 0.93$ & $4.53 \pm 0.26^{*}$ \\
Texture & Sandy loam & Loam \\
\hline
\end{tabular}

Table III. Results of ANCOVA of data from the Quebrada del Portugués and Sierra de Narváez sites and seasons.

\begin{tabular}{|c|c|c|c|c|c|c|c|c|c|}
\hline \multirow[t]{3}{*}{ Variable } & \multicolumn{9}{|c|}{ Source of variation } \\
\hline & \multicolumn{3}{|c|}{ Sites $(Z)$} & \multicolumn{3}{|c|}{ Seasons (S) } & \multicolumn{3}{|c|}{ Interaction $(\mathrm{ZxS})$} \\
\hline & $\mathrm{F}$ & d.f. & $P$ & $\mathrm{~F}$ & d.f. & $P$ & $\mathrm{~F}$ & d.f. & $P$ \\
\hline $\begin{array}{l}\text { Ectomycorrhizal } \\
\text { colonization }\end{array}$ & 0.816 & 1 & 0.369 & 0.497 & 1 & 0.482 & 3.405 & 1 & 0.069 \\
\hline
\end{tabular}

Table IV. Results of ANCOVA within cells-regression (site and season combination) of data from the six soil properties studied.

\begin{tabular}{|c|c|c|c|c|c|c|}
\hline \multirow[t]{3}{*}{ Variable } & \multicolumn{6}{|c|}{ Source of variation } \\
\hline & \multicolumn{3}{|c|}{ Soil parameters } & \multicolumn{3}{|c|}{ Error } \\
\hline & $\mathrm{F}$ & d.f. & $P$ & $\mathrm{~F}$ & d.f. & $P$ \\
\hline $\begin{array}{l}\text { Ectomycorrhizal } \\
\text { colonization }\end{array}$ & 2.639 & 6 & 0.022 & 0.497 & 70 & 0.482 \\
\hline
\end{tabular}

available $\mathrm{P}$, total $\mathrm{N}$ and organic matter) significantly influenced ectomycorrhizal colonization (Tab. IV).

Three out of the 12 morphotypes found on A. acuminata roots, showed significant differences in their percentage of occurrence as related to soil types (Tab. V). The ECM morphotypes Cortinarius tucumanensis Mos. and Gyrodon monticola Sing. were more common in the Typic Ustorthents than in Lythic Ustorthents, while Russula alnijorullensis (Sing.) Sing. was observed primarily in Lythic Ustorthents. The morphotypes Naucoria escharoides (Fr.:Fr.) Kummer and Lactarius sp. presented a different degree of colonization between sampling dates (Tab. VI). The morphotypes Tomentella sp. 1 and Tomentella sp. 3 were two of the ECM morphotypes regularly occurring at all investigated plots with an estimated proportion of $65 \%$ of all detected morphotypes.

Diversity (Simpson's diversity index) was not significantly different at the two seasons ( $\mathrm{H}: 0.38 ; P: 0.5412)$ and the two types of soil (for spring, $\mathrm{H}$ : $0.84 ; P: 0.3644$; for autumn, $\mathrm{H}$ : $0.61 ; P: 0.4396)$.

The polynomial function estimated by the multiple regression analysis showed that $18 \%\left(R^{2}=0.1845 ; P<0.05\right)$ of the
Table V. Ectomycorrhizal colonization (\%) by morphotypes in both soil types. Significance indicated as $* P<0.05$, ** $P<0.0001$. Values are means of 40 trees for each type of soil at both seasons.

\begin{tabular}{lcc}
\hline Morphotypes & \multicolumn{2}{c}{ Site } \\
\cline { 2 - 3 } & Quebrada del Portugués & $\begin{array}{c}\text { Sierra de } \\
\text { Narváez }\end{array}$ \\
\hline Cortinarius helodes & 1.237 & 0.352 \\
Cortinarius tucumanensis & 1.029 & $0.447^{*}$ \\
Alnirrhiza silkacea & 2.208 & 2.091 \\
Lactarius omphaliformis & 5.812 & 5.020 \\
Gyrodon monticola & 0.865 & $0.000^{*}$ \\
Tomentella sp. 1 & 12.500 & 19.274 \\
Naucoria escharoides & 2.871 & 3.180 \\
Tomentella sp. 2 & 5.335 & 1.964 \\
Russula alnijorullensis & 0.226 & $8.439^{* *}$ \\
Tomentella sp. 3 & 25.043 & 21.310 \\
Lactarius sp. & 0.067 & 1.647 \\
Alnirhiza amarella & 0.542 & 0.000 \\
\hline
\end{tabular}

overall variation in percentage may be explained through the variation in the independent variables (soil parameters, study sites and sampling dates). In both soil types, ECM colonization for all morphotypes together of $A$. acuminata was significantly affected only by electrical conductivity as indicated by partial regression $(\beta=0.378262, t=3.213958, P<0.05)$.

The regression relationships among ECM colonization and edaphic properties at each combination of site and sampling 
Table VI. Ectomycorrhizal colonization (\%) by morphotypes in both seasons at both sites. Significance indicated as $* P<0.05$, ** $P<$ 0.0001 . Values are means of 40 trees for each season.

\begin{tabular}{lcc}
\hline Morphotypes & \multicolumn{2}{c}{ Seasons } \\
\cline { 2 - 3 } & Autumn & Spring \\
\hline Cortinarius helodes & 0.869 & 0.720 \\
Cortinarius tucumanensis & 0.485 & 0.991 \\
Alnirrhiza silkacea & 1.707 & 2.591 \\
Lactarius omphaliformis & 4.691 & 6.141 \\
Gyrodon monticola & 0.527 & 0.337 \\
Tomentella sp. 1 & 16.644 & 15.130 \\
Naucoria escharoides & 5.299 & $0.752^{* *}$ \\
Tomentella sp. 2 & 3.910 & 3.230 \\
Russula alnijorullensis & 4.371 & 4.295 \\
Tomentella sp. 3 & 26.418 & 19.935 \\
Lactarius sp. & 1.715 & $0.000^{* *}$ \\
Alnirhiza amarella & 0.542 & 0.000 \\
\hline
\end{tabular}

dates showed some significant differences. At Sierra de Narváez (spring), the observed ECM colonization could be explained with a probability of $69 \%\left(R^{2}=0.6926 ; P<0.001\right)$ to be slightly positively dependent on $\mathrm{P}$ and positively on organic matter (Fig. 1). At Quebrada del Portugués (autumn), the observed ECM colonization could be explained with a probability of $65 \%\left(R^{2}=0.6597 ; P<0.05\right)$ to be positively dependent on field capacity, $\mathrm{pH}$ and electrical conductivity, but highly significantly negatively dependent on $\mathrm{P}$ and negatively on total nitrogen (Fig. 2). No differences were detected between ECM colonization and Sierra de Narváez in autumn $\left(R^{2}=0.2084 ; P\right.$ : $0.747)$, and ECM colonization and Quebrada del Portugués in spring $\left(R^{2}=0.2864 ; P: 0.542\right)$.

\section{DISCUSSION}

The results of this study revealed a significant influence of some soil parameters on ECM colonization of A. acuminata forests in Argentina.

There have been few reports on the level of ECM colonization in Alnus roots. In this study ECM colonization of A. acuminata ranged from 30.3 to $94 \%$, in contrast with the findings of other authors for tree genera such as Picea sp., Betula sp., Populus sp., which present high ECM colonization (> 85\%) [6, 54, 56]. However, our low results are similar to those of Helm et al. [23], which observed 30-60\% of ECM colonization in A. sinuata forests, but no further discussion on this is reported. On the other hand, Pritsch [44] found a high presence of ECM colonization in A. glutinosa forests, with values of $90 \%$. A possible reason for this variation, and for our low percentage of colonization, could be the dual presence of ectomycorrhizal/endomycorrhizal symbiosis on $A$. acuminata roots, what may bring some competition effects. However, some authors have found that in roots of some Acacia and Eucalyptus spp. both fungal symbionts can coexist without competition [18, 27], what clearly shows that further analysis may be needed on this.
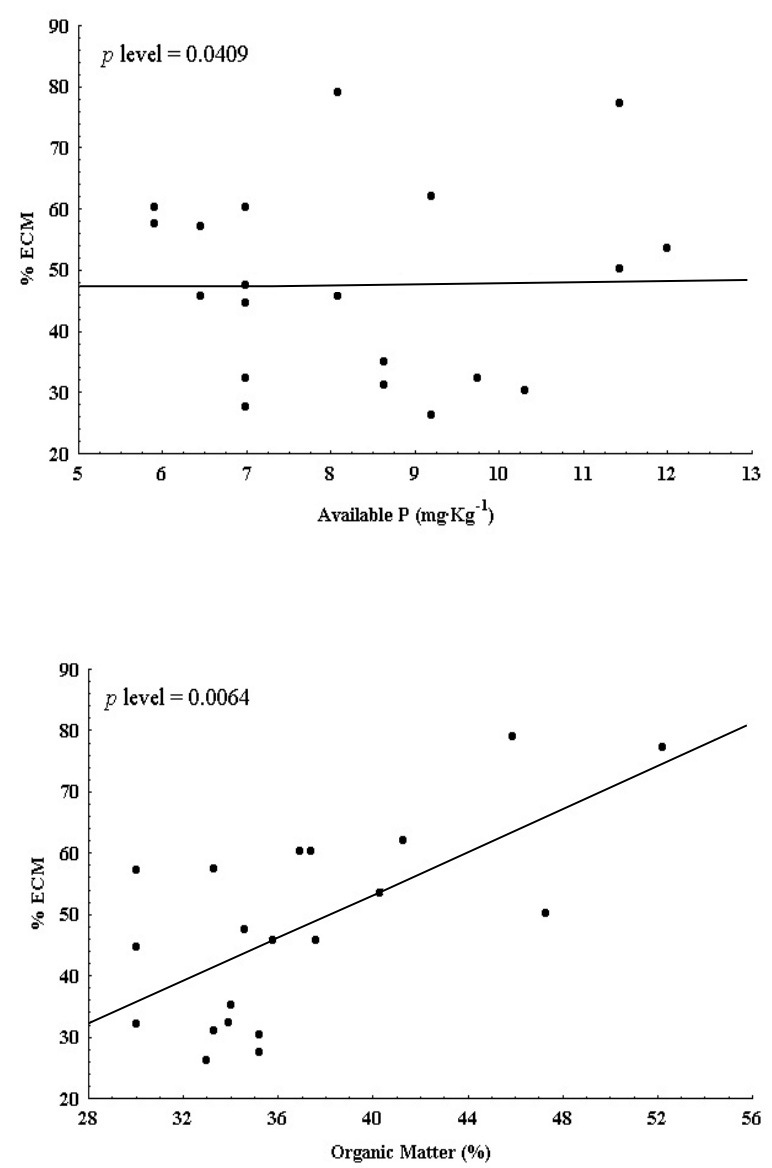

Figure 1. Regressions curve of ectomycorrhizal colonization for Sierra de Narváez (spring) and available P and organic matter.

Few studies have focused on the ectomycorrhizal community of Alnus and these studies have reported low numbers of ectomycorrhizal types $[5,9,10,23,31,45,46]$. In this study, the morphotypes Tomentella sp. 1 and Tomentella sp. 3 were abundant (65\% of all colonization). Taylor and Bruns [53] have stated that it "is clearly and excellent competitor in mature forest settings", what would somehow explain its conspicuous presence also among A. acuminata forests.

We found twelve morphotypes associated with A. acuminata. The higher percentages of morphotypes Cortinarius tucumanensis Mos. and Gyrodon monticola Sing. in the Typic Ustorthents of Catamarca Province than in the Lythic Ustorthents of Tucumán Province, is probably due to the higher organic matter content in the Typic Ustorthent soil type (Tab. II). Soil organic matter provides nutrients and retains moisture, thereby contributing to ECM activity [17, 57]. This has also been suggested by Ogawa [39], who states that Cortinarius sp. as well as some Boletales (Suillus sp., Gyrodon sp.) grow in O (organic) or A (humus) horizons, indicating a preference of these fungi for horizons with higher organic matter content.

On the other hand, a higher occurrence of the morphotype Russula alnijorrulensis (Sing.) Sing. was observed in Lythic 

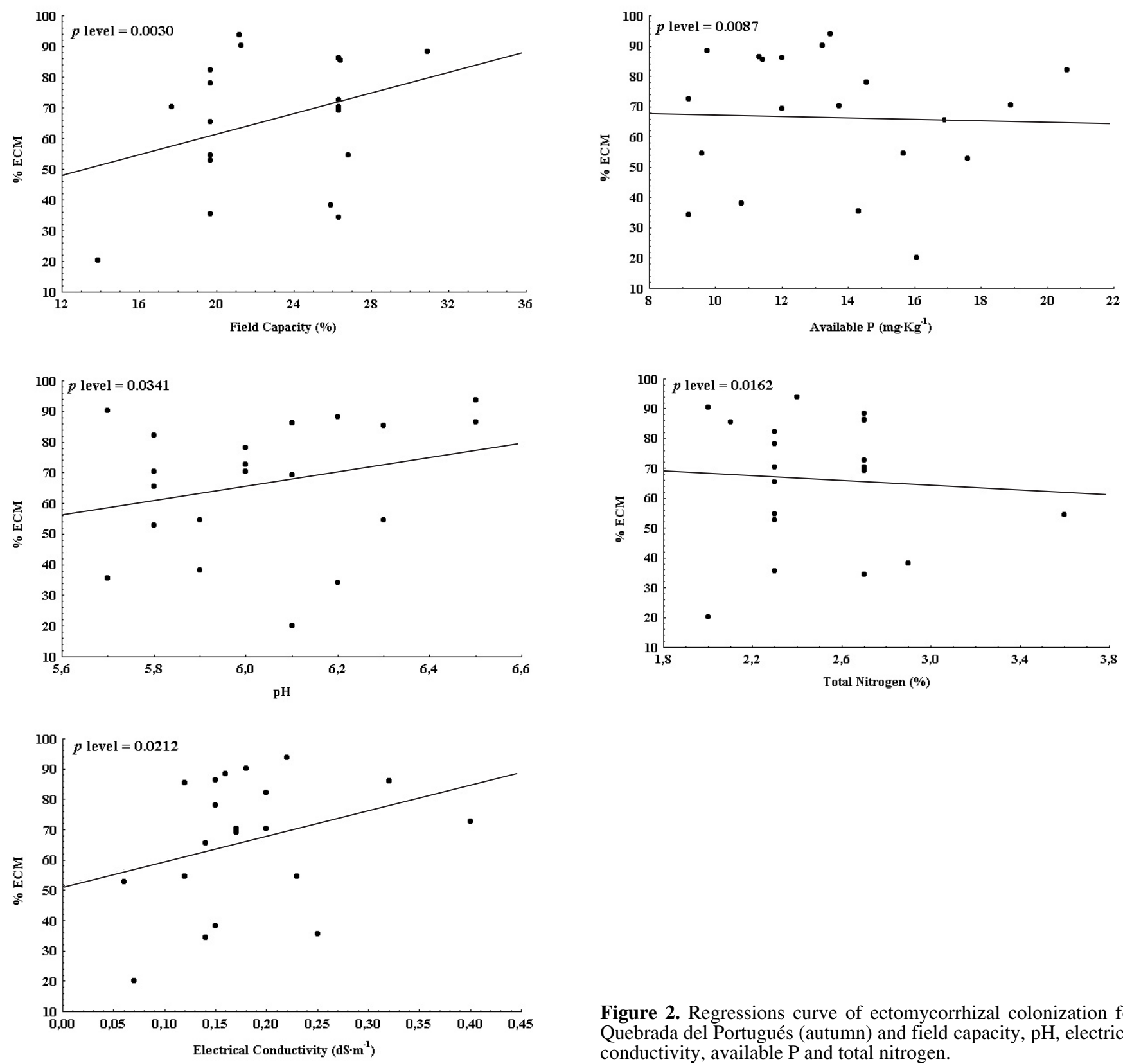

Figure 2. Regressions curve of ectomycorrhizal colonization for Quebrada del Portugués (autumn) and field capacity, $\mathrm{pH}$, electrical conductivity, available $\mathrm{P}$ and total nitrogen.

Ustorthents. This result is consistent with those of Menge et al. [30] and Lee [29]. These authors found that mycorrhizae on Pinus sp. roots were promoted by decreasing amounts of organic matter in contrast with the results found by Ogawa [39], who describes the genus Russula in horizons of fertile soils rich in organic matter.

Sampling dates differences in morphotypes Naucoria escharoides (Fr.:Fr.) Kummer and Lactarius sp., are probably due to the sensitivity of these fungi to changes in soil organic matter. Higher occurrences of these fungi in the fall can be attributed to the carbon content (allocation) in mineral horizons which reaches its peak in this season [28]. This is normally

associated with the periods of greatest root growth and mycorrhizal activity (production of mycorrhizal fruit bodies and mycelial growth) [28]. In deciduous forests such as A. acuminata this corresponds to the stage of leaf senescence, when fresh organic substrates are deposited in the litter layer [28]. The results obtained in this work coincide with those of Persson [41] where mycorrhizal roots of conifers like Pinus sylvestris attain peak of mycorrhizal activity in late autumn, at the time when concentrations of labile forms of organic nitrogen such as amino acids are greatest in the soil [1].

Diversity (Simpson's diversity index) of ECM morphotypes in the two sampling dates and the two sites studied did not differ 
significantly. Lack of differences in ECM diversity is probably due to the fact that both soils are the adequate substratum for the growth of the symbionts.

Soils in the present study have low electrical conductivity (Tab. II). The ECM colonization was positively influenced by the higher electrical conductivity of loamy stand (Sierra de Narváez), which may be related to a higher availability of mineral nutrients.

That only electrical conductivity affected ECM colonization in A. acuminata, which might be explained by the fact that the other soil parameters (field capacity, $\mathrm{pH}$, available $\mathrm{P}$, total $\mathrm{N}$ and organic matter) were not limiting factors for both, fungus and tree development. Although only some soil parameters were measured, others such as soil texture [7], bulk density [33, 51], $\mathrm{NH}_{4}{ }^{+}, \mathrm{NO}_{3}^{-}, \mathrm{SO}_{4}^{-}, \mathrm{Al}, \mathrm{Ca}, \mathrm{Cu}, \mathrm{Fe}, \mathrm{K}, \mathrm{Mg}, \mathrm{Mn}, \mathrm{Zn}$ contents, CEC $[5,37]$ and soil microorganisms $[15,42,51]$ could affect the ECM colonization.

At the two seasons of sampling, no influence on the percentage of ECM colonization was observed, in contrast to other studies, where seasonal variation in temperature, soil moisture, physiological and phenological changes in the host plant affected both symbionts [22, 52]. In this study climatic differences between the seasons were minimal (spring and autumn) [2]; which may be the reason for similar ECM colonization.

This study partially explains how ECM colonization and ECM diversity of $A$. acuminata is affected by some soil parameters and seasonal changes. Further long term studies with higher sampling frequencies are necessary to elucidate further aspects of ECM fungi, eventually some clues of their ecological relationships in the NW forests of Argentina.

Acknowledgments: This work was partially supported by PROYUNGAS (1999, 2001). We thank Eduardo Vella for technical assistance, Biol. Marcelo Zak for critical reading of the manuscript. Prof. Andrea Paula Rigalli for control of the English and Diego Cosentino for control of the French. A. B. is grateful to FOMEC and CONICET for the fellowship provided.

\section{REFERENCES}

[1] Abuarghub S.M., Read D.J., The biology of mycorrhiza in the Ericaceae XII. Quantitative analysis of individual "free" amino acids in relation to time and depth in the soil profile, New Phytol. 108 (1988) 433-441.

[2] Aceñolaza P.G., Estructura y Dinámica de bosques de aliso (Alnus acuminata H.B.K. subsp. acuminata) de la Provincia de Tucumán. Ph.D. thesis, National University of Tucumán, Argentina, 1995.

[3] Agerer R., Characterization of ectomycorrhiza, in: Norris J.R., Varma A.K., Read D.J. (Eds.), Techniques for the study of mycorrhiza, Methods in Microbiology 23, 1991, pp. 25-73.

[4] Alexander I.J., The significance of ectomycorrhizas in the nitrogen cycle, in: Lee L.A., Mc Neill S., Rorison I.H. (Eds.), Nitrogen as an Ecological Factor, Oxford, Blackwell, 1983, pp. 69-94.

[5] Baar J., Bastiaans T., Van de Coevering M.A., Roelofs J.G.M., Ectomycorrhizal root development in wet Alder carr forests in response to desiccation and eutrophication, Mycorrhiza 12 (2002) $147-151$.

[6] Baum C., Makeschin F., Effects of nitrogen and phosphorus fertilization on mycorrhizal formation of two poplar clones (Populus trichocapa and P. tremula $\times$ tremuloides), J. Plant Nutr. Soil Sci. 163 (2000) 491-497.
[7] Baum C., Weih M., Verwijst T., Makeschin F., The effects of nitrogen fertilization and soil properties on mycorrhizal formation of Salix viminalis, For. Ecol. Manage. 160 (2002) 35-43.

[8] Becerra A.G., Influencia de los Suelos Ustorthentes sobre las ectomicorrizas y endomicorrizas de Alnus acuminata H.B.K., Master thesis, University of Buenos Aires, Argentina, 2002.

[9] Becerra A., Daniele G., Domínguez L., Nouhra E., Horton T., Ectomycorrhizae between Alnus acuminata H.B.K. and Naucoria escharoides (Fr.:Fr.) Kummer from Argentina, Mycorrhiza 12 (2002) 6166.

[10] Becerra A., Nouhra E., Daniele G., Domínguez L., McKay D., Ectomycorrhizas of Cortinarius helodes and Gyrodon monticola with Alnus acuminata from Argentina, Mycorrhiza 15 (2005) 7-15.

[11] Bower C.A., Wilcox L.W., Soluble salts, in: Methods in Soil Analysis: Agronomy, in: CA Black (Ed.), No. 9, Part 2, 1 st ed, Am. Soc. Agron., Inc., Madison WI., 1965, pp. 933-951.

[12] Bremner J.M., Mulvaney C.S., Chemical and microbiological properties, in: Page A.L., Miller R.H., Keeney D.R. (Eds.), Methods of soil analysis, Part 2, 2nd ed., Am. Soc. Agron., Inc., Madison, 1982, pp. 595-624.

[13] Brundrett M., Mycorrhizas in natural ecosystems, Adv. Ecol. Res. 21 (1991) 171-262.

[14] Cervantes E., Rodríguez-Barrueco C., Relationships between the mycorrhizal and actinorrhizal symbioses in non-legumes, in: Norris J.R., Read D.J., Varma A.K. (Eds.), Methods in Microbiology 24, Academic Press, London, 1992, pp. 417-432.

[15] Duponnois R., Founoune H., Lesueur D., Influence of the controlled dual ectomycorrhizal and rhizobal symbiosis on the growth of Acacia mangium provenances, the indigenous symbiotic microflora and structure of plant parasitic nematode communities, Geoderma 109 (2002) 85-102.

[16] El Karkouri K., Martin F., Mousain D., Dominance of the mycorrhizal fungus Rhizopogon rubescens in a plantation of Pinus pinea seedlings inoculated with Suillus collinitus, Ann. For. Sci. 59 (2002) 197-204.

[17] Fogel R., Hunt G., Fungal and arboreal biomass in a western Oregon Douglas-fir ecosystem: distribution patterns and turnover, Can. J. For. Res. 9 (1979) 245-256.

[18] Founoune H., Duponnois R., Bâ A.M., El Bouami F., Influence of the dual arbuscular endomycorrhizal/ectomycorrhizal symbiosis on the growth of Acacia holosericea (A. Cunn ex G. Don) in glasshouse conditions, Ann. For. Sci. 59 (2002) 93-98.

[19] Gehring C.A., Whitham T.G., Comparisons of ectomycorrhizae on pinyon pines (Pinus edulis; Pinaceae) across extremes of soil type and herbivory, Amer. J. Bot. 81 (1994) 1509-1516.

[20] Godbout C., Fortin J.A., Morphological features of synthesized ectomycorrhizae of Alnus crispa and Alnus rugosa, New Phytol. 94 (1983) 249-262.

[21] Grau A., La expansión del aliso del cerro (Alnus acuminata H.B.K. subsp. acuminata) en el noroeste de Argentina, Lilloa 36 (1985) 237-247.

[22] Harvey A.E., Jurgensen M.F., Larsen M.J., Seasonal distribution of ectomycorrhizae in a mature Douglas-fir/larch forest soil in western Montana, For. Sci. 24 (1978) 203-208.

[23] Helm D.J., Allen E.B., Trappe J.M., Mycorrhizal chronosequence near Exit Glacier, Alaska, Can. J. Bot. 74 (1996) 1496-1506.

[24] Helm D.J., Allen E.B., Trappe J.M., Plant growth and ectomycorrhiza formation by transplants on deglaciated land near Exit Glacier, Alaska, Mycorrhiza 8 (1999) 297-304.

[25] Henrion B., Chevalier G., Martin F., Typing truffle species by PCR amplification of the ribosomal DNA spacers, Mycol. Res. 98, 37-43.

[26] Jackson M.L., Análisis químico de suelos, Omega, Barcelona, 1964.

[27] Lapeyrie F., Chilvers G.A., An endomycorrhiza-ectomycorrhiza succession associated with enhanced growth of Eucalyptus dumosa seedlings planted in a calcareous soil, New Phytol. 100 (1985) 93-104. 
[28] Leake J.R., Read D.J., Mycorrhizal fungi in terrestrial habitats, in Wicklow D.T., Söderström B. (Eds.), The Mycota IV. Environmental and microbial relationships, Springer-Verlag, Berlin, 1997, pp. 281-301.

[29] Lee K.J., Correlation between ectomycorrhizal formation in Pinus and organic matter, nitrogen, phosphorus contents and acidity in the forest soil, in: Proceedings, 17th IUFRO Congress, Ibaeaki, Kyoto, 1981, pp. 83-87.

[30] Menge J.A., Grand L.F., Haines L.W., The effect of fertilization on growth and mycorrhizae numbers in 11 years-old loblolly pine plantations, For. Sci. 23 (1977) 37-44.

[31] Miller S.L., Koo C.D., Molina R., Characterization of red alder ectomycorrhizae: a preface to monitoring belowground ecological responses, Can. J Bot. 69 (1991) 516-531.

[32] Moser M., Some aspects of Cortinarius associated with Alnus, Journées Européennes du Cortinaire 3 (2001) 47-101.

[33] Moyersoen B., Fitter A.H., Alexander I.J., Spatial distribution of ectomycorrhizas and arbuscular mycorrhizas in Korup National Park rain forest, Cameroon, in relation to edaphic parameters, New Phytol. 139 (1998) 311-320.

[34] Moyersoen B., Becker P., Alexander I.J., Are ectomycorrhizas more abundant than arbuscular mycorrhizas in tropical heath forest? New Phytol. 150 (2001) 591-599.

[35] National Academy of Sciences, Especies para leña; árboles y arbustos para la producción de energía, CATIE, Turrialba, Costa Rica, 1984.

[36] Nelson D.W., Sommers L.E., Total carbon, organic carbon, and organic matter, in: Page A.L., Miller R.H., Keeney D.R. (Eds.), Methods of soil analysis, Part 2, American Society of Agronomy, Inc., Madison WI., 1982, pp. 639-577.

[37] Neville J., Tessier J.L., Morrison I., Scarratt J., Canning B., Klironomos J.L., Soil depth distribution of ecto- and arbuscular mycorrhizal fungi associated with Populus tremuloides within a 3-yearold boreal forest clear-cut, Appl. Soil Ecol. 19 (2002) 209-216.

[38] Newbery D.M., Alexander I.J., Thomas D.W., Gartlan J.S., Ectomycorrhizal rain-forest legumes and soil phosphorus in Korup National Park, Cameroon, New Phytol. 109 (1998) 433-450.

[39] Ogawa M., Ecological characters of ectomycorrhizal fungi and their mycorrhizae. An introduction to the ecology of higher fungi, JARQ 18 (1985) 305-314.

[40] Peech M., Hydrogen-ion activity, in: Methods in Soil Analysis: Agronomy, in: CA Black (Ed.), No. 9, Part 2, 1st ed., Am. Soc. Agron., Inc., Madison WI., 1965, pp. 914-926.

[41] Persson H.A., The distribution and productivity of fine roots in boreal forest, Plant Soil 71 (1983) 87-101.

[42] Poole E.J., Bending G.D., Whipps J.M., Read D.J., Bacteria associated with Pinus sylvestris-Lactarius rufus ectomycorrhizas and their effect on mycorrhiza formation in vitro, New Phytol. 151 (2002) 743-751.
[43] Pritchett W.L., Fischer R.F., Tropical Forest Soils, in: Properties and Management of Forest Soils,Wiley Sons J. (Ed.), 2nd ed., New York, 1987, pp. 308-328.

[44] Pritsch K., Untersuchungen zur Diversität und Ökologie von Mykorrhizen der Schwarzerle [Alnus glutinosa (L.) Gaertn.], Ph.D. thesis, University of Tübingen, Germany, 1996.

[45] Pritsch K., Boyle H., Munch J.C., Buscot F., Characterization and identification of black alder ectomycorrhizas by PCR/RFLP analyses of the rDNA internal transcribed spacer (ITS), New Phytol. 137 (1997) 357-369.

[46] Pritsch K., Munch J.C., Buscot F., Morphological and anatomical characterisation of black alder Alnus glutinosa (L.) Gaertn. ectomycorrhizas, Mycorrhiza 7 (1997) 201-216.

[47] Raithelhuber J., Flora Micológica Argentina, Hongos II, Mycosur, 1988

[48] SAS Institute, SAS/EIs software reference, version 6.0, 2nd ed., SAS Institute, Cary, N.C., 1995.

[49] Simpson E.H., Measurement of diversity, Nature 163 (1949) 688.

[50] Singer R., Morello J.H., Ectotrophic forest tree mycorrhizae and forest communities, Ecology 41 (1960) 549-551.

[51] Slankis V., Soil factors influencing formation of mycorrhizae, Ann. Rev. Phytopathol. 12 (1974) 437-457.

[52] Swaty R.L., Gehring C.A., Van Ert M., Theimer T.C., Keim P., Whitman T.G., Temporal variation in temperature and rainfall differentially affects ectomycorrhizal colonization at two contrasting sites, New Phytol. 139 (1998) 733-739.

[53] Taylor D.L., Bruns T.D., Community structure of ectomycorrhizal fungi in a Pinus muricata forest: minimal overlap between the mature forest and resistant propagule communities, Mol. Ecol. 8 (1999) 1837-1850

[54] Tedersoo L., Kõljalg U., Hallenberg N., Larsson K.-H., Fine scale distribution of ectomycorrhizal fungi and roots across substrate layers including coarse woody debris in a mixed forest, New Phytol. 159 (2003) 153-165.

[55] Veihmeyer F.J., Hendrickson A.H., The moisture equivalent as a measure of the field capacity of soils, Soil Sci. (1931) 181-194.

[56] Visser S., Maynard D., Danielson R.M., Response of ecto- and arbuscular mycorrhizal fungi to clear-cutting and the application of chipped aspen wood in a mixedwood site in Albert, Canada, Appl. Soil Ecol. 7 (1998) 257-269.

[57] Vogt K.A., Edmonds R.L., Grier C.C., Seasonal changes in biomass and vertical distribution of mycorrhizal and fibrous-textured conifer fine roots in 23-and 180-year-old sub-alpine Abies amabalis stands, Can. J. For. Res. 17 (1981) 239-245.

[58] White T.J., Bruns T., Lee S., Taylor J., Amplification and direct sequencing of fungal ribosomal RNA genes for phylogenetics, in: Innis M.A., Gelfand D.H., Sninsky J.J., White T.J. (Eds.), PCR Protocols: a guide to methods and applications, New York, Academic Press, 1990, pp. 315-322. 